\title{
CHARACTERISTICS AND KNOWLEDGE ON HIV/AIDS AMONG MEN WHO HAVE SEX WITH MEN IN SEMARANG, CENTRAL JAVA
}

\author{
Arwinda Nugraheni, Diah Rahayu Wulandari, Teddy Wahyu N, Firdaus \\ Wahyudi, Suharto, Dodik Pramono
}

Departement of Public Health, Faculty of Medicine, Universitas Diponegoro

\begin{abstract}
Background: In 33 countries that reported, data coverage of men who have sex with other men (MSM) with HIV prevention programmes ranges from $21 \%$ to $80 \%$. MSM carry out activities at risk of being infected with HIV/AIDS. Cases of HIV/AIDS in MSM groups continue to increase every year. Studies into MSM and knowledge of HIV/AIDS are still rare. This study aimed to describe the characteristics and knowledge on HIV/AIDS among MSMs in Semarang, Central Java.

Subjects and Method: This was cross-sectional study conducted in Semarang, Central Java, from June to August 2018. A total of 78 MSMs selected for this study. The study variables in this study included age, education, employment status, income, and knowledge of HIV/AIDS. The data were collected by questionnaire and in-depth interview. The data were analyzed descriptively.

Results: $58 \%$ of MSMs were >25 years old, $78 \%$ had high school education, $69 \%$ worked, and 19.2\% had income above the minimum wage. The range of MSMs knowledge on HIV/AIDS was 12.5 to $100.61 \%$ of MSM had poor knowledge (<75), 22\% had good knowledge (75 to 99), and 12\% had very good knowledge (100). The lowest knowledge was during incubation and prophylactic prevention.

Conclusion: MSM knowledge about HIV AIDS is still lacking. It is expected that there will be an increase in knowledge of HIV/AIDS especially regarding the incubation period and prevention of prophylaxis after dealing with HIV/AIDS sufferers.
\end{abstract}

Keywords: MSM, HIV/AIDS, knowledge

Correspondence:

Arwinda Nugraheni. Departement of Public Health, Faculty of Medicine, Universitas Diponegoro, Jl. Prof. H. Soedarto, SH., Tembalang-Semarang 50275, Semarang, Central Java. Email: arwindanugraheni@gmail.com. Mobile: 02476928010.

The 5th International Conference on Public Health Best Western Premier Hotel, Solo, Indonesia, February 13-14, $2019 \mid 248$

https://doi.org/10.26911/theicph.2019.02.53 